NOTE

\title{
Antibody binding following exposure of live Ichthyophthirius multifiliis (Ciliophora) to serum from immune carp Cyprinus carpio
}

\author{
M. L. Cross* \\ Department of Biological Sciences, University of Plymouth, Plymouth PL4 8AA, United Kingdom
}

\begin{abstract}
Trophont stages of the ciliate fish parasite Ichthyophthirius multifiliis were incubated alive in vitro in serum from immune carp Cyprinus carpio and subsequently examined immunohistologically for bound antibody. Parasites became immobilized in immune serum and were enveloped by gelatinous mucus-lıke material. Carp antibody could not be detected bound to cilia membranes (the major surface antigens), although it was detected at low levels in parasite food vacuoles and associated with the gelatinous material. This material is probably responsible for the immobilization of parasites, and may form a barrier that prevents access of large amounts of cilia-membrane-specific antibody to the parasite surface during in vitro incubation in fish serum.
\end{abstract}

KEY WORDS: Antibody Carp - Ichthyophthirius multifilis Mucocytes

The holotrich ciliate Ichthyophthirius multifiliis is a major pathogen of freshwater fish worldwide (Nigrelli et al. 1976). Despite the marked pathogenicity of the disease (Hines \& Spira 1974a, Ventura \& Paperna 1985), fish which survive an initial infection can develop protective immunity and produce humoral antibodies specific to the parasite (Hines \& Spira 1974b, Wahli \& Meier 1985, Clark et al. 1987, 1988). The major antigenic targets comprise integral proteins of the cilia membranes (Clark et al. 1988), and the contents of secretory mucocyst organellae (Cross \& Matthews 1993). When parasites are incubated alive in vitro in immune fish serum they become immobilized, and gelatinous material is discharged from the mucocysts (Clark et al. 1987, Houghton 1987). However, the precise mode by which immobilization occurs is uncertain; in particular it is unclear whether this reflects direct agglutination of cilia via antibody-binding to the membrane anti-

\footnotetext{
- Present address and address for correspondence: Department of Veterinary Science, University of Arizona, Tucson, Arizona 85721, USA
}

gens, or whether immobilization occurs via a secondary effect. In the present study, the binding of antibody to $I$. multifilis is determined at the ultrastructural level, following incubation of parasites alive in immune carp Cyprinus carpio serum, to identify the factor(s) responsible for in vitro immobilization.

Methods. Ichthyophthirius multifiliis was isolated from freshwater fish obtained from local aquarists (Carassius auratus, held at $20^{\circ} \mathrm{C}$ ), and maintained in the laboratory by routine passage in naive hosts (Cyprinus carpio, held at $20^{\circ} \mathrm{C}$ ). To collect trophonts, fish were held temporarily in a glass vessel containing a small volume of buffered tap water ( $\mathrm{pH} 7.2)$; the agitated movements of fish in such an enclosed environment caused trophonts to be released from the skin. Within 2 to $3 \mathrm{~min}$ of release, groups of approximately 20 trophonts were collected with a glass pasteur pipette and transferred to $0.5 \mathrm{ml}$ perspex vials containing a minimum volume of fresh buffered tap water. $100 \mu 1$ of immune or control carp serum was then added to each vial to give a final dilution of $1 / 4$ in water. The immune serum, which was derived from adult carp that had been immunized against $I$. multifiliis by controlled infections, was known to contain antibodies against cilia membrane antigens and the contents of secretory mucocyst organellae (Cross \& Matthews 1993). The control serum, which was derived from similar-sized non-infected carp, was known to be non-reactive against parasite antigens (Cross \& Matthews 1993). Following $1 \mathrm{~h}$ incubation at room temperature (approximately $22^{\circ} \mathrm{C}$ ), trophonts were washed copiously with clean water, and subsequently fixed, embedded and sectioned for immunohistology as described previously (Cross \& Matthews 1993).

Carp immunoglobulin was detected in tissue sections by immunogold labelling techniques, performed 
according to Cross \& Matthews (1993). These procedures utilized a rabbit anti-carp IgM serum that had been produced by immunizing male Dutch rabbits with chromatography-purified IgM fractions (Cross \& Matthews 1993). Labelling was performed at both light and electron microscope levels. Briefly, for light level microscopy, semithin tissue sections on glass slides were labelled using 1/8 rabbit anti-carp IgM serum, which had been commercially conjugated with $15 \mathrm{~nm}$ colloidal gold (Biocell, Cardiff, UK), and the signal was amplified using an Intense- $M$ silver enhancing kit (Janssen, UK). For electron microscopy, ultrathin tissue sections on nickel grids were labelled using $1 / 20$ rabbit anti-carp IgM serum and $1 / 30$ goat anti-rabbit IgG 20 $\mathrm{nm}$ colloidal gold conjugate (Bioclin, UK). The antiserum controls for immunogold labelling procedures involved using pre-immune rabbit serum as the primary antibody, or omitting the primary antibody step.
The efficacy of the above labelling procedures had been confirmed previously, by employing the same techniques and antisera to detect endogenous carp immunoglobulin within tissue sections of carp epidermis (Cross 1990)

Results. Trophonts which were incubated in vitro in immune carp serum became immobilized within 5 to $10 \mathrm{~min}$, and ceased all further motion. Upon microscopic examination, immobilized trophonts were observed to be enveloped by gelatinous mucuslike material. Histologically, this material was amorphous, appearing beyond the outer face of the peripheral cilia, and creating a halo effect around each trophont which gave a weak silver-enhanced signal for carp IgM under blue light (Fig. 1A). Uitrastructurally, the amorphous material displayed weak immunogold labelling specific for carp immunoglobulin, although there was little evidence of antibody associated with
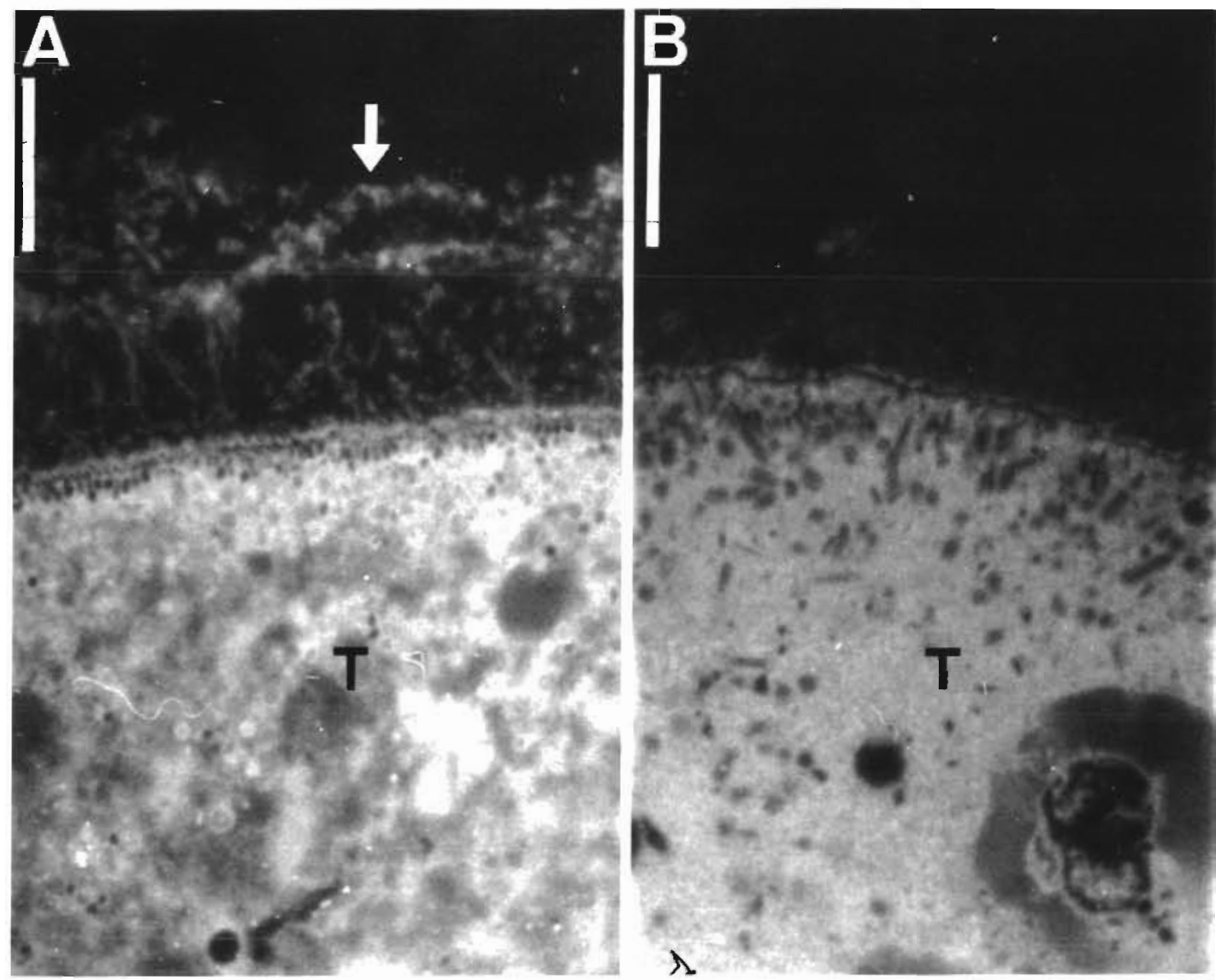

Fig. 1. Ichthyophthirius multifilis. Light micrographs of the peripheral surface of trophonts (T) labelled by immunogold specific for carp IgM and silver stained, following in vitro incubation in (A) serum from carp Cyprinus carpis immunized aqainst $I$. multifiliis by repeated infections or (B) control serum from carp naive to $l$. multifilis. Slides viewed under blue light. Note light diffraction by silver associated with the secreted amorphous material beyond the outer edge of the cilia in (A) (arrowed), which is surrounding the outer surface of the parasite. $\times 2000$; scale bars $=10 \mu \mathrm{m}$. Resin section, counter-stained with $1 \%$ methylene blue 


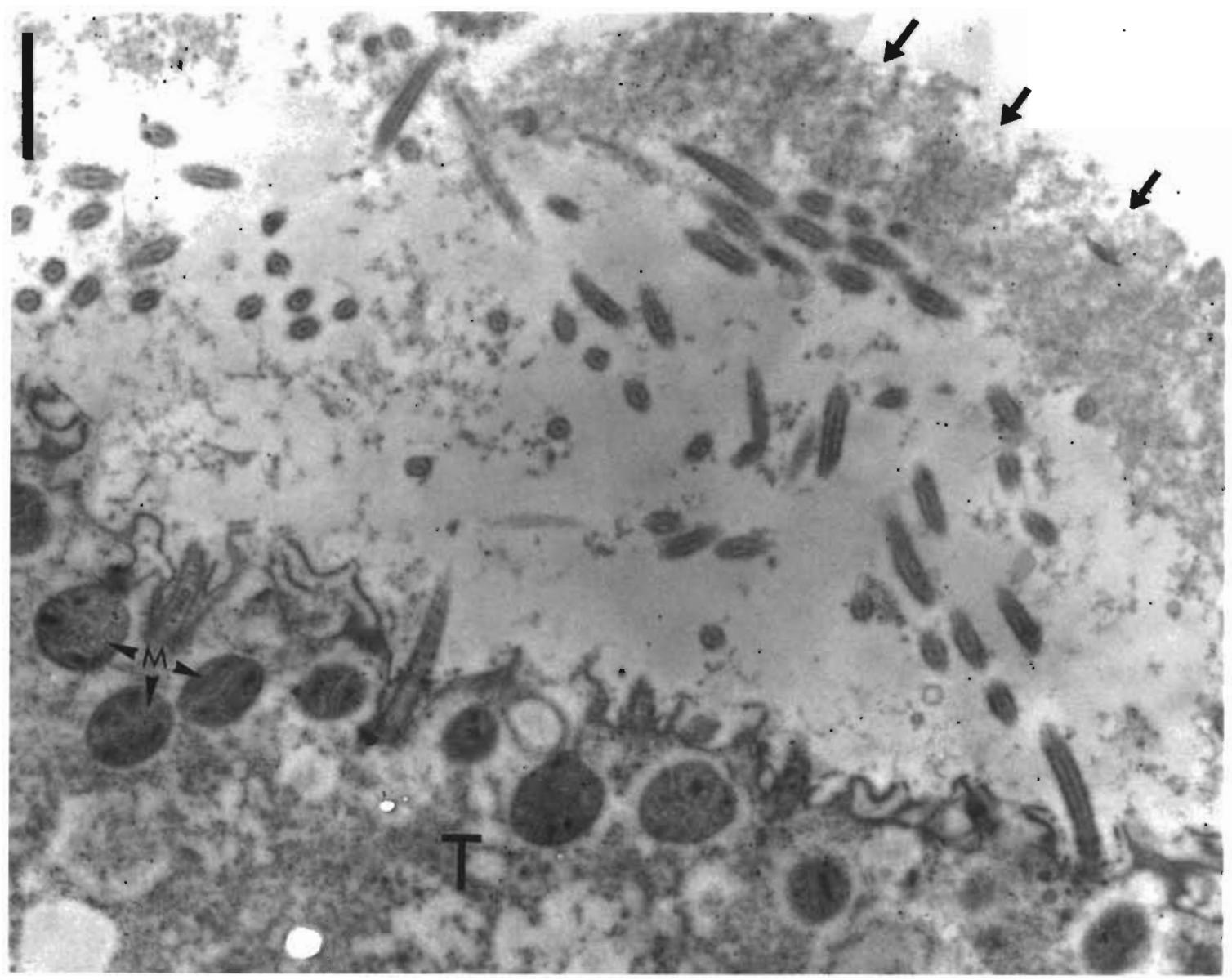

Fig. 2. Ichthyophthirius multifiliis. Electron micrograph of a trophont (T) following in vitro incubation in serum from carp Cyprinus carpio immunized by repeated infections, showing specific immunogold labelling for carp IgM in the amorphous material (arrowed). Note that the precipitate reaction occurs beyond the outer edge of the peripheral cilia and not in direct contact with the parasite surface. M: swollen mitochondria of the parasite. $\times 13300$; scale bar $=1 \mu \mathrm{m}$

the surface or peripheral cilia of the parasite (Fig. 2). In contrast, trophonts in control carp serum were still active after $1 \mathrm{~h}$ incubation, although their mobility was reduced. No gelatinous material was observed on these trophonts and there was no appreciable surface labelling for carp antibody (Figs. 1B \& 3). However, gold labelling for carp IgM was recorded in trophont food vacuoles, regardless of whether the parasites had been incubated in immune or control serum (Fig. 4).

Discussion. Following in vitro incubation in immune carp serum, trophonts became immobilized and secreted gelatinous material, as documented previously by other workers studying effects of specific immune sera on Ichthyophthirius multifiliis as well as freeliving ciliates (Alexander 1967, Doerder \& Berkowitz 1986, Clark et al. 1987). Surprisingly, significant amounts of carp immunoglobulin were not detected on the ciliated surfaces of these parasites, even though in a previous study it had been shown that this carp serum contains high levels of antibody directed against antigens associated with the surface membranes of cilia, in both theront and trophont stages (Cross \& Matthews 1993). It is probable that the mucocyst-derived gelatinous material prevented access of large amounts of antibody to the parasite surface. The structural nature of this material is uncertain, although it probably comprises complex mucopolysaccharides, similar to mucocyst material of the free-living ciliate Tetrahymena pyriformis (Nilsson 1979. Wolfe 1988). What is clear, from microscopic observations, is that this material ensheathed each parasite, forming a gelatinous capsule-like layer. A similar response has been recorded following incubation of $T$. pyriformis in specific immune mammalian antiserum, and it has been suggested that this capsule forms a barrier, produced as a protective response on the part of the ciliate (Nilsson 1979). In I. multifiliis, Ewing et al. (1985) have recorded mucocyst discharge during the epithelial penetration process; whether mucus production in vivo 


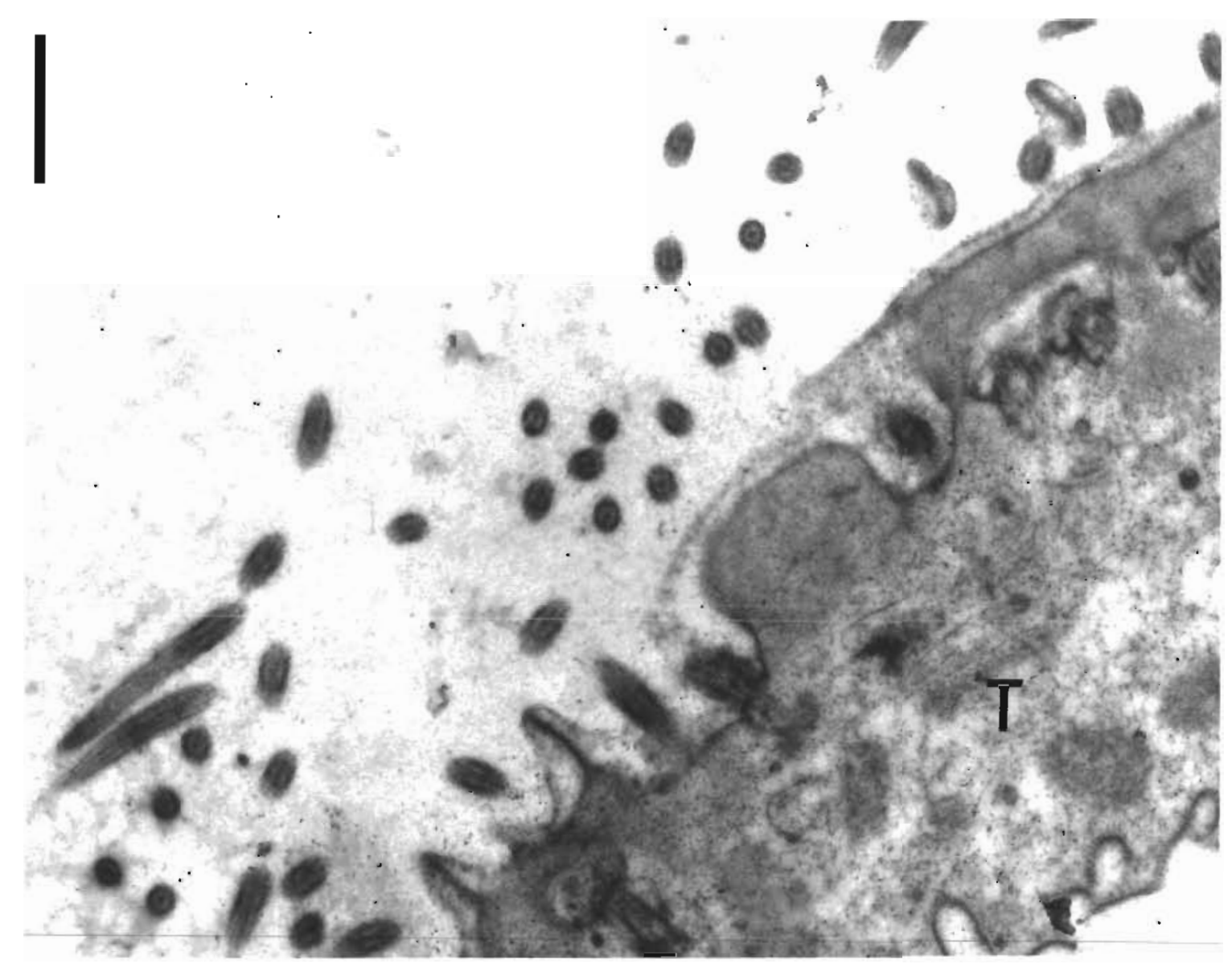

Fig. 3. Ichthyophthirius multifilis. Electron micrograph of a trophont (T), following in vitro incubation in control serum from carp Cyprinus carpio naive to I. multifilis, immunogold labelled for carp IgM. Note the lack of any amorphous material (as in Fig. 2), or any specific labelling. $\times 16000$; scale bar $=1 \mu \mathrm{m}$

performs a similar protective function to the proposed in vitro response, and whether this is sufficient to prevent antibodies reaching the parasite surface during penetration of immune fish, is uncertain at this stage. However, since I. multifiliis is known to be able to penetrate the skin of immune carp (Cross \& Matthews 1992), this represents a possible mechanism of immune evasion by the parasite.

Results here demonstrate that in vitro immobilization of Ichthyophthirius multifiliis can occur without detectable levels of antibody binding to cilia membranes, suggesting that a secondary factor, most likely mucus secretion by the parasite, is responsible for immobilization. This agrees with the hypothesis of Clark et al. (1987), who also questioned whether multivalent IgMmediated cross-linking of cilia would be sufficient to impede the strong swimming motion of I. multifilis. The fact that the gelatinous capsule material gave a weak immunogold signal specific for carp immunoglobulin reflects antibody binding to antigens of the discharged mucocyst contents, since the carp anti- serum used here is known to contain antibodies specific for components of this material (Cross \& Matthews 1993). Whether this response has any deleterious effect on the protective function of the gelatinous barrier is uncertain, although lytic complement products resulting from antibody activation might play a role in degrading this layer. It does not appear, however, that this is sufficient to affect the macromolecular impermeability of the capsule, since no antibody binding to the cilia membranes could be detected. In addition to labelling associated with the gelatinous layer, specific labelling for carp IgM was also detected in trophont food vacuoles, regardless of whether the parasites had been incubated in control or immune carp serum. Since IgM has also been detected within food vacuoles of mature trophozoites developing in the skin of carp (Cross 1990), it is considered here that this labelling pattern represents immunoglobulin which had entered the parasite via ingestion during its parasitic stage. There was no obvious damage associated with antibody uptake to the cytoplasm, and the immunolabel was most 


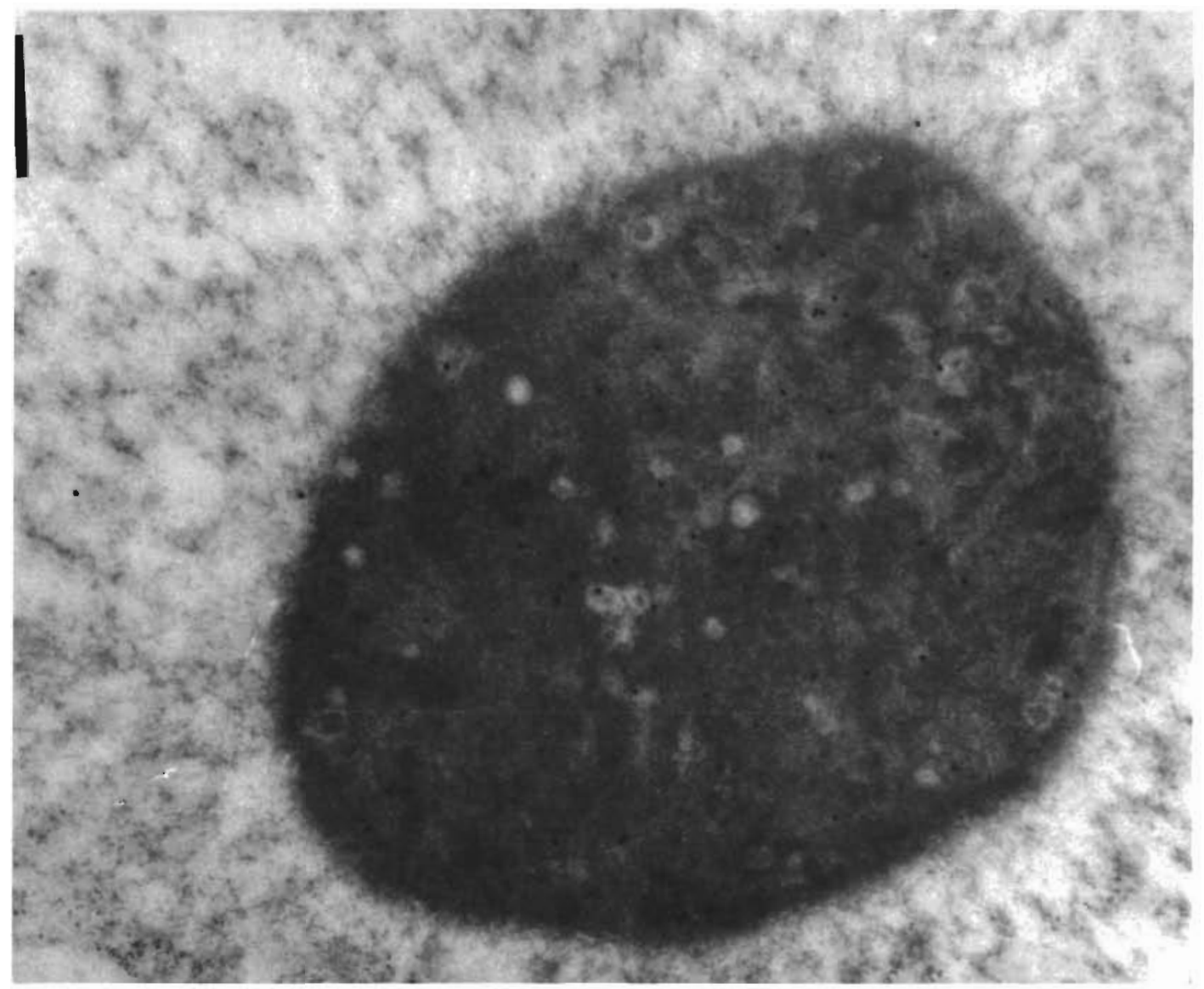

Fig. 4. Ichthyophthirius multifiliis. Electron micrograph of a trophont food vacuole, showing specific immunogold labelling for carp Cyprinus carpio IgM. $\times 16000$; scale bar $=1 \mu \mathrm{m}$

probably detecting residual epitopes of the carp immunoglobulin molecule; it seems unlikely that any activity would have remained in antibodies processed in food vacuoles.

Acknowledgements. Thanks are due to Dr B. F. Matthews (University of Plymouth) for her help in the development of immunogold labelling techniques. This work was supported by a research studentship from the Science and Engineering Research Council awarded to M.L.C., and a research grant awarded to Dr R. A. Matthews (University of Plymouth) by the Polytechnic Central Funding Committee.

\section{LITERATURE CITED}

Alexander, J. B. (1967). A new immobilization test for Tetrahymena pyriformis. Trans. Am. microsc. Soc. 86: $421-427$

Clark, T G., Dickerson, H. W., Findly, R. C. (1988). Immune response of channel catfish to ciliary antigens of Ichthyophthirius multifilis. Dev. comp. Immunol. 12: $581-594$
Clark, T G., Dickerson, H. W., Gratzek, J B., Findly, R. C (1987). In vitro response of Ichthyophthirius multifiliis to sera from immune channel catfish. J Fish Biol. 31(A): 203-208

Cross, M. L. (1990). The immune response of carp Cyprinus carpio L. to Ichthyophthirius multifiliis Fouquet, with reference to events within the epidermis. Ph.D. thesis, Polytechnic South West, Plymouth, U.K.

Cross, M. L., Matthews, R. A. (1992). Ichthyophthiriasis in carp Cyprinus carpio L.: fate of parasites in immunized fish. J. Fish Dis. 15: 497-505

Cross, M. L., Matthews, R. A. (1993). Ichthyophthirius multifiliis Fouquet (Ciliophora): the location of sites immunogenic to the host Cyprinus carpio L. Fish Shellfish Immunol. 3: 13-24

Doerder, F. P., Berkowitz, M. S. (1986). Purification and partial characterisation of the $H$ immobilization antigen of Tetrahymena thermophila. J. Protozool. 33: $204-208$

Ewing, M. S., Kocan, K. M., Ewing, S. A. (1985). Ichthyophthirius multifiliis (Ciliophora): invasion of gill epithelium. J. Protozool. 32: 305-310

Hines, R. S., Spira, D. T (1974a). Ichthyophthiriasis in the mirror carp Cyprinus carpio L. III. Pathology. J. Fish Biol. 6: $189-200$

Hines, R. S., Spira, D.T (1974b). Ichthyophthiriasis in the mirror carp Cyprinus carpio L. V. Acquired immunity. J. Fish Biol. 6: $373-378$ 
Houghton, G. (1987). The immune response in carp, Cyprinus carpio L. to Ichthyophthirius multifilis, Fouquet 1876. Unpublished Ph. D. thesis, Plymouth Polytechnic, Plymouth. U.K.

Nigrelli, R. F., Pokorny, A. S., Ruggieri, G. D. (1976). Notes on Ichthyophthirius multifilis, a ciliate parasite on freshwater fishes, with some remarks on possible physiological races and species. Trans. Am. microsc. Soc. 95: $607-613$

Nilsson, J. R. (1979). Phagotrophy in Tetrahymena. In: Levandowsky, M., Hunter, S. H. (eds.) Biochemistry and

Responsible Subject Editor: W. Körting, Hannover, Germany physiology of protozoology, Vol. 2. Academic Press. New York, p. 339-380

Ventura, M. T., Paperna, I. (1985). Histopathology of Ichthyophthirius multifiliss infections in fishes. J. Fish Bıol. 27: $185-203$

Wahli, T., Meier, W. (1985). Ichthyophthiriasis in trout: investigations of natural defence mechanisms. In: Ellis, A. E. (ed.) Fish and shellfish pathology. Academic Press, London, p. 347-352

Wolfe, J. (1988). Analysis of Tetrahymena mucocyst material with lectins and alcian blue. J. Protozool. 35: 46-51

Manuscript first received: March 9, 1993

Revised version accepted: July 22, 1993 